Sergei Bogatyrev (University College London)

\title{
Three Takes on One Legend: Polyphony in Muscovite Court Culture
}

The reign of Tsar Ivan IV the Terrible (1533-1584) saw an outburst of cultural activities ranging from redecorating the Kremlin after a major fire to the creation of the Illustrated Chronicle Compilation (Litsevoi letopisnyi svod). What drew these ambitious projects that generated thousands of painted images and thousands of written pages? Soviet scholars believed that it was the political idea of centralization that resulted in the monopoly of royal authority over culture. D. S. Likhachev argued that Muscovite culture under Ivan IV was dominated by socalled second monumentalism. In his view, this official pompous style turned literature into a servant of the state by imposing on literary works, including the Illustrated Chronicle Compilation, a single restrictive task of glorifying Muscovy's past and present. ${ }^{1}$

Modern scholarship has abandoned the extremes of this political interpretation of Muscovite culture. Still, students tend to reduce the Muscovite views of Ivan IV's monarchy to a set of fossilized ideas emanating from one intellectual center. Cultural studies contributed to this interpretation by applying to Muscovite artistic works the concept of a school borrowed from art criticism. Scholars particularly often speak about the school of Metropolitan Makarii. He was undoubtedly a prominent cultural figure, but the parameters of the Makarian

This paper has benefitted from the comments of two anonymous readers. I am also grateful to Michael Flier for sharing his paper "Branching Out: The Roots of Muscovite Dynastic Representation" and for his advice about the imagery of the Golden Hall. All interpretations and errors remain mine.

${ }^{1}$ D. S. Likhachev, "Na puti k novomu literaturnomu soznaniiu," in Pamiatniki literatury Drevnei Rusi. Vtoraia polovina XVI veka, ed. L. A. Dmitriev, D. S. Likhachev (Moscow: Khudozhestvennaia literatura, 1986), 5. 
school have never been properly defined. ${ }^{2}$ This vagueness allows for apologetic literature, which has flourished after Makarii's canonization in 1988, to attribute to the school of Makarii practically every cultural development in the second half of the sixteenth century. ${ }^{3}$ Despite more sophisticated methodology, semiotic and anthropological studies also offer a reductionist view of Muscovite culture. Semiotic works highlight the image of the tsar as a sacral figure invested with divine power. ${ }^{4}$ Students inspired by anthropological studies emphasize the idea of cooperation between the tsar and the boyars in Muscovite imagery. ${ }^{5}$

All these interpretations suggest a monolithic top-down view of kingship to which Muscovite bookmen and artists fully subscribed. This is very different from what contemporary scholarship tells us about court culture in other premodern societies. According to Kevin Sharpe, in Western Europe early modern courts employed unstable texts containing a multiplicity of meanings and significations and open to various, shifting and contesting interpretations. Representation of power was not a result of total control of the monarch over cultural production. Rather it was a matter of negotiation among various

2 O. I. Podobedova, Moskovskaia shkola zhivopisi pri Ivane IV. Raboty v Moskovskom Kremle 40-kh - 70-kh godov XVI v. (Moscow: Nauka, 1972), 5-9, 88. Podobedova wrote about the Moscow school, the school of Makarii, and the school of Ivan the Terrible. She provided some formal characteristics of the Moscow school, but never explained the relationship between that and the two other schools.

${ }^{3}$ For a modern clerical take on Metropolitan Makarii, see Archimandrite Makarii, (Veretennikov), Zhizn'i trudy sviatitelia Makariia, mitropolita Moskovskogo i vseia Rusi (Moscow: Izdatel'skii sovet Russkoi pravoslavnoi tserkvi, 2002), 201283.

${ }^{4}$ B. A. Uspenskii, V. M. Zhivov, "Tsar and God: Semiotic Aspects of the Sacralization of the Monarch in Russia,' in B. A. Uspenskii, V. M. Zhivov, 'Tsar and God" and Other Essays in Russian Cultural Semiotics, ed. Marcus C. Levitt (Boston: Academic Studies Press, 2012), 1-112 (first published in Russian in 1987). ${ }^{5}$ Robert O. Crummey, "Court Spectacles in Seventeenth-Century Russia: Illusion and Reality," in Essays in Honor of A. A. Zimin, ed. Daniel Clarke Waugh (Columbus, OH: Slavica Publishers Inc., 1985), 138; Daniel Rowland, "Biblical Military Imagery in the Political Culture of Early Modern Russia: The Blessed Host of the Heavenly Tsar," in Medieval Russian Culture 2, ed. Michael S. Flier and Daniel Rowland (Berkeley: University of California Press, 1994): 182-212. 
patrons, creators and the audience. ${ }^{6}$ Such polyphony was not limited to Western Christian monarchies. In his study of Islamic rulership A. Azfar Moin also presents a composite and multidimensional picture of sacred kingship embracing "charismatic and rational, transgressive and conformist, performative and doctrinal, mythical and historical." He concludes that the experience of Moghul sacred kingship resulted not only from royal patronage, but also from popular practices and public performances. ${ }^{7}$

Both in Western Europe and the Moghul Empire court culture generated contesting interpretations of kingship. Tudor cultural production capitalized on Renaissance rhetoric which required engaging both sides of an argument. In Moghul India, official chronicles defended the ruler from accusations of heresy levied in other polemical works, including a chronicle secretly written by a courtier. ${ }^{8}$ Unlike Tudor England, Ivan IV's Muscovy did not encounter pamphlets that assaulted the concept of divine kingship. ${ }^{9}$ Evidence about the secret engagement of one of Ivan IV's courtiers in chronicle writing remains murky, despite optimistic attempts to reconstruct that private chronicle. ${ }^{10}$ Generally speaking, the cultural output of Muscovite bookmen and artists was narrower than that of their West Christian and Islamic counterparts. Printing remained incipient, and many forms of creative work were completely missing from Ivan IV's Muscovy. A favorite topic of Western-centric comparative studies, this "cultural deficiency" included theatre, poetry, instrumental music, secular arts and literature.

${ }^{6}$ Kevin Sharpe, Selling the Tudor Monarchy. Authority and Image in SixteenthCentury England (New Haven, London: Yale University Press, 2009), 21, 22, 25, $43,47,82$

${ }^{7}$ A. Azfar Moin, The Millennial Sovereign. Sacred Kingship and Sainthood in Islam (New York: Columbia University Press, 2012), 124, 239 (Nook edition). 8 Sharpe, Selling, 36; Moin, The Millennial Sovereign, 172, 175, 185-88.

${ }^{9}$ Cf. Sharpe, Selling, 309.

10 Ia. G. Solodkin, "Taina 'khronik' boiarina I. F. Mstislavskogo: K istorii chastnogo letopisaniia v Rossii XVI v.," Trudy Otdela drevnerusskoi literatury 57 (2006): 945-949; A. S. Usachev, "Kniaz' I. F. Mstislavskii - zabytyi knizhnik XVI veka?" Vestnik Nizhnevartovskogo gosudarstvennogo gumanitarnogo universiteta (hereafter VNGGU) 1 (2011): 15-24. 
Compared to other court cultures, the Muscovite world of anonymous creators and silent audience seems to be misty and sleepy, but is this impression correct? A while ago Daniel Rowland noted that "Muscovite writers relied not on one but on several images of the tsar, each deeply embedded in a long literary history stretching back to Byzantium."11 According to modern studies, meanings shifted and morphed in Muscovite cultural practices under the influence of various agencies and circumstances. ${ }^{12}$ In line with this discriminating approach, this paper will argue that Muscovite views of royal power included subtle but important polyphony. It will focus on the visual representation of a major foundation myth of the Muscovite monarchy, the legend about the gifts of Emperor Constantine Monomachus. Finalized during the reign of Vasilii III (1505-1533), the legend is both naïve and elegant: Prince Vladimir Monomakh of Kyiv (1113-1125) organized a campaign against the Byzantine emperor Constantine Monomachus, who appeased Vladimir by sending him imperial regalia, including Constantine's own cap. The emperor's representatives solemnly crowned the prince of Kyiv with the Cap of Monomachus, setting an example for all his successors, including the rulers of Moscow.

Despite well-known anachronisms, like Vladimir Monomakh being only two years old when Constantine died in 1055, the legend frequently appeared in Muscovite literature, art and diplomatic records. Literary adaptations of the legend include several influential works. One of them, the Tale about the Princes of Vladimir (Skazanie o kniaz'iakh Vladimirskikh, hereafter Tale) treats the story about imperial regalia in the context of fanciful genealogies of Muscovite and

11 Daniel Rowland, "Did Muscovite Literary Ideology Place Limits on the Power of the Tsar (1540s-1660s)?” The Russian Review 49, 2 (1990): 151.

12 Sergei Bogatyrev, "The Heavenly Host and the Sword of Truth: Apocalyptic Imagery in Ivan IV's Muscovy," in The New Muscovite Cultural History: A Collection in Honor of Daniel B. Rowland, ed. Valerie Kivelson and others (Bloomington, IN: Slavica Publishers, 2009), 88-89; Valerie Kivelson and Jonathan Shaheen, "Prosaic Witchcraft and Semiotic Totalitarianism: Muscovite Magic Reconsidered," Slavic Review 70, 1 (2011): 25. See also Gail Lenhoff's critique of Likhachev's theory of literary etiquette that overblows the stability of Muscovite culture. Gail Lenhoff, Early Russian Hagiography: The Lives of Prince Fedor the Black (Slavistische Veröffentlichungen Fachbereich Neuere Fremdsprachliche Philologien der Freien Universität Berlin 82, 1997), 200, 201, 212-213. 
Lithuanian princes. Another adaptation entitled The Installation of the Great Princes of Rus' (Postavlenie velikikh kniazei ruskikh, hereafter Installation) is based on the Tale and focuses specifically on the origin of Muscovite royal insignia from Constantinople and Kyiv. The Installation served as an ideological foundation text for the coronation of Ivan IV as tsar in 1547.13

After Ivan's coronation anonymous masters ${ }^{14}$ transformed the narrative of the Installation into visual programs by creating three impressive series of illustrations: the murals of the Golden Hall (Zolotaia palata) in the royal palace in the Kremlin, which were destroyed together with the hall itself in 1762 and are known thanks to an inventory compiled by the undersecretary Nikita Klement'ev and the famous iconpainter Simon Ushakov in 1672; the bas-reliefs of the roofed box pew, known as the Tsar's Pew (Tsarskoe mesto), in the Dormition Cathedral of the Moscow Kremlin; and the miniatures of the Illustrated Chronicle Compilation. ${ }^{15}$ In addition to images, all these visual programs utilized adopted text of the legend about Monomachus' gifts. The Tsar's Pew features even two versions of the text: one in captions accompanying the bas-reliefs, and another, fuller version, on the low doors in the front of the Pew.

The structure of the above mentioned programs can be found in the table in the Appendix. Columns contain the location of images (walls of the Golden Hall, external sides of the Tsar's Pew and folios of the Illustrated Chronicle Compilation) as well as individual scenes identified with the indicator of their iconographic program (GH for the Golden Hall, TP for the Tsar's Pew, and ICC for

13 R. P. Dmitrieva, Skazanie o kniaz'iakh vladimirskikh (Moscow, Leningrad: Izdatel'stvo Akademii nauk SSSR), 171-178, 182-184

14 Here and below I use "master," "miniaturist" and other similar terms in a broad sense with reference to an individual or a group of individuals responsible for conceiving and executing visual images.

15 Golden Hall: I. E. Zabelin, Materialy dlia istorii, arkheologii i statistiki goroda Moskvy 1 (Moscow: Moskovskaia gorodskaia duma, 1884): 1247-1249; Tsar's Pew: I. M. Sokolova, Russkaia dereviannaia skul'ptura XV-XVIII vekov. Katalog (Moscow: Gos. istoriko-kul'turnyi muzei-zapovednik “Moskovskii Kreml'”, 2003), 26-58 (hereafter Skul'ptura); Illustrated Chronicle Compilation: Litsevoi letopisnyi svod XVI veka. Russkaia letopisnaia istoriia 1 (Moscow: Akteon, 2009): 3-9 (hereafter $L L S-R L I$ ). 
the Illustrated Chronicle Compilation) followed by consecutive number. As the Appendix shows, the number of scenes in all programs is approximately the same. This means that quantitative factors did not affect the narrative strategies of the programs.

To facilitate comparison, scenes depicting the same subject appear in the same row of in the table. Thematic and compositional parallels suggest that the illustrative cycles are interrelated. But the directions of influence are sometimes unclear because two of the programs, those of the Golden Hall and the illustrated chronicle cannot be dated precisely. The old view that all the three programs appeared simultaneously in the middle of the sixteenth century should be abandoned. ${ }^{16}$ Despite different opinions about the exact dating of the Illustrated Chronicle Compilation, scholars agree now that it was created after the Golden Hall and the Tsar's Pew. ${ }^{17}$ As for the Tsar's Pew, its bas-reliefs surely date to 1551.18

The murals of the Golden Hall were created after 1547, when a fire damaged the room together with other buildings in the Kremlin. The images can be thus broadly dated to the period between the fire of 1547 and 1672, the year Klement'ev and Ushakov catalogued the murals. More precisely, the murals appeared before 1554, because some of them are mentioned in the records of the 1554 trial of Secretary Ivan Viskovatyi, who criticized the new imagery in renovated Kremlin buildings. ${ }^{19}$ The narrow dating of the murals to the period

16 For that view, see Podobedova, Moskovskaia shkola, 22-23.

17 The Illustrated Chronicle Compilation was still work in progress in the 1570s. According to B. M. Kloss, the chronicle was compiled between 1568 and 1576, while V. V. Morozov dates the completion of the chronicle to 1586 because its later copy covers the beginning of the reign of Fedor Ivanovich. Morozov rejects the idea that the section on Fedor, which reveals signs of editing, is a later addition, arguing that the entire Illustrated Chronicle Compilation was edited in one go in 1586. In fact, the editing of the chronicle was a multi-phase process (see below). B. M. Kloss, Nikonovskii svod i russkie letopisi XVI-XVII vekov (Moscow: Nauka, 1980), 222-226, 249; V. V. Morozov, Litsevoi svod v kontekste otechestvennogo letopisaniia XVI veka (Moscow: Indrik, 2005), 253-254.

18 On the dating of the Tsar's Pew, see Sokolova, Skul'ptura, 55-56.

19 David B. Miller, "The Viskovatyi Affair of 1553-54: Official Art, the Emergence of Autocracy, and the Disintegration of Medieval Russian Culture," Russian 
from 1547 to 1554 still does not explain what came first, the imagery of the

Golden Hall or the bas-reliefs of the Tsar's Pew (1551). According to Russian historians, the murals of the Golden Hall are later than the images of the Tsar's Pew. ${ }^{20}$ At the same time, Michael Flier argues for the end of work on the murals in 1551, i.e. before the Tsar's Pew. ${ }^{21}$ Indeed, as we will see below, the imagery of the Golden Hall affected the bas-reliefs of the Tsar's Pew. It is possible that the murals underwent some alterations after Ivan IV, but these changes were abortive and did not affect the program to any significant extent. ${ }^{22}$

History 8, 3 (1981): 308. Attempts to discard the materials of the Viskovatyi affair as a historical source are ill-advised. See Sergei Bogatyrev, "Reinventing the Russian Monarchy in the 1550s. Ivan the Terrible, the Dynasty, and the Church," The Slavonic and East European Review 85 (2007), 2: 281 note 46. On the dating of the murals to the late 1540s or the 1550s, see Podobedova, Moskovskaia shkola, 59; Daniel Roulend (Daniel Rowland), "Dve kul'tury - odin tronnyi zal," in Drevnerusskoe iskusstvo. Russkoe iskusstvo pozdnego srendevekov'ia, XVI vek, ed. A. L. Batalov and others (St. Petersburg: Dmitrii Bulanin, 2003), 197; Daniel Rowland, "Architecture, Image, and Ritual in the Throne Rooms of Muscovy, 1550-1650: A Survey of Sources," in Rude and Barbarous Kingdom Revisited. Essays in Russian History and Culture in Honor of Robert O. Crummey, ed. Chester S. L. Dunning and others (Bloomington, IN: Slavica Publishers, 2008), 63.

20 For late dates of the murals (after 1551), see K. K. Lopialo, "K primernoi rekonstruktsii Zolotoi palaty Kremlevskogo dvortsa i ee monumental'noi zhivopisi," in Podobedova, Moskovskaia shkola, 196; V. V. Morozov, A. V. Chernetsov, "Legenda o Monomakhovykh regaliiakh v iskusstve Moskvy XVI v.," in Rim, Konstantinopl', Moskva. Stavnitel'no-istoricheskoe issledovanie tsentrov ideologii i kul'tury do XVII v., ed. A. N. Sakharov and others (Moscow: Institut rossiiskoi istorii, 1997), 368; Sokolova, Skul'ptura, 55. Late dating often fails to take into account the materials of the Viskovatyi trial and misinterprets some murals of the Golden Hall as allegorical representation of the taking of Kazan in 1552. Those scenes, which depicted the military exploits of Gideon and Joshua, referred not to Kazan, but to Ancient Israel as a model for the Muscovite tsardom. Cf. Podobedova, Moskovskaia shkola, 65-66;

${ }^{21}$ Michael S. Flier, "Branching Out: The Roots of Muscovite Dynastic Representation". Paper presented at the conference "Rethinking Early Modern Russia" at Yale University in April 2015. Flier's earlier article dated the end of work on the murals to 1553. Maikl Flaer (Michael Flier), "K semioticheskomu analizu Zolotoi palaty Moskovskogo Kremlia," in Drevnerusskoe iskusstvo. Russkoe iskusstvo pozdnego srendevekov'ia, 178.

${ }^{22}$ According to Michael Flier, the reign of Fedor Ivanovich saw the addition of two images to the murals, those of St. Tsarevich Dmitrii Ivanovich of Uglich (Fedor's half-brother) and St. Theodore Stratilates (Fedor's patron saint). Flier, "Branching Out." On the image of Dmitrii Ivanovich, see below. 


\section{The Golden Hall}

Illustrations to the Monomakh legend were part of the Golden Hall's royal imagery that emphasized the prominence of the prince in Muscovite culture and the association between him and God. Scholars have drawn direct parallels between the images of princes in the Golden Hall and other major representations of dynastic themes in works attributed to the patronage of Metropolitan Makarii, like the murals of the Archangel Cathedral and the Book of Degrees of the Royal Genealogy (Stepennaia kniga tsarskogo rodosloviia). ${ }^{23}$ This attribution is not free from anachronisms, because the murals of the Archangel cathedral and the Book of Degrees postdate Makarii's death in 1563 and should be associated with Makarii's successor Afanasii. Still, what is more important for the subject of this paper is that the program of the Golden Hall treated royal images very differently from the murals of the cathedral and the text of the Book of Degrees. The master of the cathedral and the compiler of the Book of Degrees conveyed powerful images of a united and ancient royal clan by stressing the kin ties between various princes. ${ }^{24}$ In contrast with these representations of linear kinship, the royal imagery of the Golden Hall defies genealogy. As Flier notes, the program of the Golden Hall clearly prioritized the spiritual and historical status of certain Rus' princes over continuous bloodline. ${ }^{25}$

\footnotetext{
23 Podobedova, Moskovskaia shkola, 60; Flaer, "K semiotike," 181-184; Daniel Rowland, "Two Cultures, One Throne Room: Secular Courtiers and Orthodox Culture in the Golden Hall of the Moscow Kremlin," in Orthodox Russia: Belief and Practice Under the Tsars, ed. Valerie A. Kivelson, Robert H. Greenne (University Park, PA: The Pennsylvania State University Press, 2003), 42; Michael S. Flier, "Golden Hall Iconography and the Makarian Initiative," in The New Muscovite Cultural History, 68.

24 T. E. Samoilova, Kniazheskie portrety v rospisi Arkhangel'skogo sobora Moskovskogo Kremlia. Ikonograficheskaia programma XVI veka (Moscow: Progress-Traditsiia, 2004); A. S. Usachev, Stepennaia kniga i drevnerusskaia knizhnost' vremeni mitropolita Makariia (Moscow, St. Petersburg: Al'ians-Arkheo, 2009), 533-534, 623-628; A. V. Sirenov, Stepennaia kniga i russkaia istoricheskaia mysl' XVI-XVIII vv. (Moscow, St. Petersburg: Al'ians-Arkheo, 2010), 53-54, 104111.

25 Flier, "Branching Out."
} 
The location of the murals illustrating the Monomakh legend in relation to other royal images is essential to our understanding of the artist's take on the legend. The royal portraiture in the Golden Hall contained three groups of images. ${ }^{26}$ One group included the images of St. Vladimir I (ca 980-1015), his sons SS Boris and Gleb, Andrei Bogoliubski, Alexander Nevskii, Mikhail Iaroslavich of Tver', Ivan Vasil'evich (Ivan III?) and Vasilii III on the vaults. A second group of images, which were located on the walls, included two cycles flanking the tsar's throne, one illustrating the baptism of St. Vladimir I and another depicting the legend about imperial regalia (see Appendix). A third set of murals painted in the surrounds above the windows represented waist-high images of certain Vsevolod,27 Vladimir Monomakh, Vasilii Vasil'evich (II), St. Theodore Stratilates, Dmitrii Ivanovich Donskoi, Ivan Ivanovich (II), Daniil Aleksandrovich, certain Dmitrii Ivanovich of Uglich, St. Fedor Rostislavich of Iaroslavl' with his sons, SS Davyd and Konstantin. ${ }^{28}$

It is surprising that the main protagonist of the legend about imperial regalia, Vladimir Monomakh appeared separately from the cycle of murals representing the legend itself. Illustrations to the legend were located on the southern, western and northern walls of the chamber, whereas the image of Vladimir

26 On the murals' locations, see Flaer, "K semioticheskomu analizu," 183.

27 Probably St. Vsevolod-Gavrill Mstislavich, prince of Pskov in 1137-1138, whose name also concludes a list of royal saints in Ivan IV's memorial list of Rus' princes prepared for their commemoration in Constantinople in 1556-1557. See Rossiia i Grecheskii mir v XVI veke 1, ed. S. M. Kashtanov (Moscow: Nauka, 2004): 398. Less likely candidatures include Vladimir Monomakh's father Vsevolod Iaroslavich or Vsevolod Iur'evich Big Nest. 28 Zabelin, Materialy 1: 1245-1249. The identity of the second image of Dmitrii Ivanovich is complex. The inscription accompanying that image described him as grand prince of Uglich. The most famous member of royalty associated with Uglich was Tsarevich Dmitrii, the canonized son of Ivan IV. However, the title fits neither Tsarevich Dmitrii nor any other member of the royal clan and is obviously corrupt. Apparently, the image originally represented Grand Prince Dmitrii Ivanovich, grandson of Ivan III, and was later carelessly reinterpreted as a representation of St. Dmitrii of Uglich. Despite famous rivalry between Ivan IV's father Vasilii III and Grand Prince Dmitrii Ivanovich, the latter's memory became part of a collective image of the royal clan in the 1550s (see Rossiia i Grecheskii mir 1: 399, 403 note 47). For the artist of the Golden Hall, who was interested in regalia and coronations, Grand Prince Dmitrii Ivanovich was important as the first member of the royal family to be publicly crowned in 1498. 
Monomakh was on the eastern wall, above murals illustrating the baptism of St. Vladimir. At the same time, the image of St. Vladimir, which was placed on the southeastern vault next to the tsar's throne, played a central part in both cycles: it concluded the sequence of scenes representing St. Vladimir's baptism and simultaneously opened the mural series devoted to the history of royal insignia. The image of St. Vladimir therefore served as a visual link between the story about baptism and the story about imperial regalia. This spatial arrangement of royal imagery indicates that the master of the Golden Hall associated the legend about imperial gifts not with Vladimir Monomakh, but with St. Vladimir. ${ }^{29}$

In his treatment of the legend the artist of the Golden Hall capitalized on the confused and confusing memory of Vladimir Monomakh in East Slavic culture. ${ }^{30}$ The visual representation of the legend in the Golden Hall was based on the text of the Installation, which conflates the memories of two Vladimirs. The Installation dates the obtaining of imperial regalia by Vladimir Monomakh to 6496 (988). We have already seen that Muscovite interpretations of the legend never bothered with precise chronology. In this case the year of 6496 is of course the date of St. Vladimir's baptism, as the Installation's main source, the Tale about the Princes of Vladimir correctly reports. The compiler of the Installation reworked the Tale by leaving out the material about St. Vladimir. However, he kept the date of St. Vladimir's baptism. Deprived of its original context, the date

${ }^{29}$ On the conflation of the images of two Vladimirs, see also I. M. Sokolova, Monomakhov tron. Tsarskoe mesto Uspenskogo sobora Moskovskogo Kremlia. $K$ 450-letiiu pamiatnika (Moscow: Indrik, 2001), 61-62 note 157.

${ }^{30}$ Earlier chronicles hopelessly muddled Vladimir Monomakh's genealogy and were uncertain about whether it was him or St. Vladimir who established the city of Vladimir on the Kliaz'ma. Ivan IV's diplomats also confused two Vladimirs. The compilers of the 1556-57memorial list of Rus' princes erred in Vladimir Monomakh's baptismal name, giving Andrei instead of Vasilii. Polnoe sobranie russkikh letopisei 3 (Moscow: Iazyki russkoi kul'tury, 2000): 465-467 (hereafter PSRL); PSRL 16 (Moscow: Iazyki russkoi kul'tury, 2000): 309, note 2; A. A. Kuznetsov, "K izucheniiu letopisnykh dat osnovaniia Vladimira na Kliaz'me," VNGGU 1 (2011): http://cyberleninka.ru/article/n/k-izucheniyu-letopisnyh-datosnovaniya-vladimira-na-klyazme, last accessed 5 February 2016; Rossiia i Grecheskii mir 1: 398, 402 note 14-14; Dmitrieva, Skazanie, 121; K. Iu. Erusalimskii, "Istoriia na posol'skoi sluzhbe: Diplomatiia i pamiat' v Rossii XVI veka," in Istoriia i pamiat': Istoricheskaia kul'tura Evropy do nachala novogo vremeni, ed. L. P. Repina (Moscow: Krug, 2006), 695-697. 
was now associated with the story about Vladimir Monomakh obtaining royal regalia. ${ }^{31}$ This conflation of images of two Vladimirs in the literary tradition of the Monomakh legend inspired the visual association of the legend with St. Vladimir in the murals of the Golden Hall. ${ }^{32}$ St. Vladimir became a central figure in the narrative that created overarching parallels between the Old Testament and Kyivan archetypes of rulership on the one hand, and the present tsar, Ivan IV of Moscow on the other. ${ }^{33}$ In the program of the Golden Hall, St. Vladimir assumed not only his traditional part of baptizer, but also the role of triumphant winner of royal insignia.

This reinvented image of St. Vladimir called for a reworking of the legend about imperial regalia. The illustrative program of the Golden Hall was based on rather peculiar textual version of the legend. In some parts it followed the variant of the legend recorded in the Voskresenskaia chronicle, like calling the royal headgear the Cap of Monomachus (Manamakhova shapka). ${ }^{34}$ Some details of the program are missing from the chronicle, but appear in other literary works employing the legend. 35

\footnotetext{
31 Dmitrieva, Skazanie, 50.

32 The association between the legend about imperial gifts and St. Vladimir was supported with inscriptions accompanying the illustrations to the legend. These inscriptions did not employ the sobriquet Monomakh, consistently calling the main hero of the legend just Vladimir, and ignored the Installation's information about Vladimir Monomakh being a fourth-generation descendant from St. Vladimir. In contrast, the waist-high portrait of Vladimir Monomakh above one of the windows featured a caption that properly identified the prince with his nickname Monomakh.

33 On the theme of Ancient Israel in the vestibule of the Golden Hall, see Flier, "Golden Hall Iconography," 72-75.

34 Zabelin, Materialy 1: 1248; PSRL 7 (Moscow: Iazyki russkoi kul'tury, 2001): 23. Other literary adaptations of the legend employ the generic term "imperial crown" (tsarskii venets). Dmitrieva, Skazanie, 164, 165, 177, 183, 184; L'idea di Roma a Mosca secoli XV-XVI. Fonti per la storia del pensiero sociale russo, ed. Pierangelo Catalano and others (Rome: Herder, 1989), 26, 27; cf. Sokolova, Skul'ptura, 26, 29.

35 See the passage about Vladimir appointing thousand-man, hundred-man and fifty-man battalion leaders prior to his campaign against Constantine in Zabelin, Materialy 1: 1248; Dmitrieva, Skazanie, 163, 176, 183, 190, 193; L'idea, 26.
} 
Certain passages reproduced in the Golden Hall cannot be found in any known version of the legend. In particular, literary adaptations of the legend tell us that Vladimir dispatched his troops without mentioning his personal participation in the campaign. ${ }^{36}$ At the same time, inscriptions in the Golden Hall insisted that Vladimir himself led his army in the campaign against Constantinople: "when Prince Vladimir and his commanders went to Constantinople, Emperor Constantine Monomachus was in Constantinople then..."37 Following that text, the artist depicted Vladimir in armor at the head of his cavalry proceeding to a town by the sea (Appendix, GH-3a). The Golden Hall also featured a scene of the emperor's emissaries leaving Constantinople for Kyiv on horseback (GH-5b), another episode missing from the existing texts of the legend. It is hard to say whether these unique elements of the program come from an unknown literary version of the legend or were added by the decorators of the Hall. Whatever their origin, these parts are important for establishing connections between the visual programs of the Golden Hall and the Tsar's Pew (see below).

What is obvious that the inscriptions of the Golden Hall employed a particular reworking of the legend that radically reinterpreted the history of Vladimir Monomakh's coronation. Early variants of the legend attributed the idea of coronation to Emperor Constantine, who gave his emissaries instructions to go to Kyiv and to crown Vladimir Monomakh, but did not describe the coronation itself. On the contrary, in the program of the Golden Hall, the coronation became the culmination of the whole story. Furthermore, according to inscriptions accompanying the murals, the initiative of coronation belonged not to the emperor's will, but to the desire and blessing of the Holy Trinity. This view of coronation resulting from divine rather than human inspiration finds parallels in the versions of the Monomakh legend included in the Great Menology (Velikie Chetii Minei) commissioned by Metropolitan Makarii and the Book of Degrees compiled by Metropolitan Afanasii. ${ }^{38}$ Following this religious interpretation of

\footnotetext{
${ }^{36}$ Dmitrieva, Skazanie, 163, 176, 183, 190, 193, 198; L'idea, 26; PSRL 7: 23; Sokolova, Skul'ptura, 26, 33.

37 Zabelin, Materialy 1: 1248.

38 Velikiia Minei Chetii, sobrannyia Vserossiiskim mitropolitom Makariem. Sentiabr', dni 14-24 (hereafter VMCh) (Moscow: Tipografiia Imp. Akademii nauk,
} 
the legend, the artist of the Golden Hall represented the divine force that caused Vladimir's coronation as the New Testament Trinity (Paternitas or Otechestvo, GH-7a), which featured an anthropomorphic representation of God the Father. ${ }^{39}$

Focus on Vladimir's coronation also affected the ending of the story about imperial gifts. The Installation tells us that since Vladimir Monomakh all great princes of Vladimir had been crowned with the Cap of Monomachus. But in the illustrative program of the Golden Hall this ending is missing because it became redundant in the context of the master's aim to present the coronation as a triumph of divine will and logical continuation of the story about St. Vladimir's baptism of Rus'.

The mural cycles illustrating the history of baptism and royal regalia encircled the room, focusing on the throne of Ivan IV. This spatial arrangement placed the figure of the present monarch amidst never-ending mythological past: the viewer could observe the story about baptism flowing into the story of coronation, whose end brought the viewer back to the representation of St. Vladimir's baptism. In the program of Golden Hall, the legend about the Cap of Monomachus was detached from its main character, Vladimir Monomakh and became part of timeless narrative focusing on the image of St. Vladimir. It was St. Vladimir who appeared in the murals of the Golden Hall as the main protagonist of royal mythology exemplifying the spiritual and military virtues of a true Orthodox prince.

1869), col. 1318; Stepennaia kniga tsarskogo rodosloviia po drevneishim spiskam 1, ed. N. N. Pokrovskii, G. D. Lenhoff (Moscow: Iazyki slavianskikh kul'tur, 2007): 409. On common sources utilized in the inscriptions of the Golden Hall and the Great Menology, see Maikl Flaer (Michael Flier), "V rutse Isusu: K voprosu o novgorodskom vliianii v nastennykh nadpisiakh Zolotoi palaty Kremlia," in Translation and Tradition in "Slavia Orthodoxa", ed. Valentina Izmirlieva, Boris Gasparov (Berlin: Lit Verlag, 2012), 132-140.

${ }^{39}$ On the iconography of Paternitas, see L. S. Retkovskaia, "0 poiavlenii i razvitii kompozitsii 'otechestvo' v russkom iskusstve XIV-XVI vekov," in Drevnerusskoe iskusstvo XV-nachala XVI vekov (Moscow: Izdatel'stvo AN SSSR, 1963), 235-262. 
The Tsar's Pew

The Dormition cathedral, which houses the Tsar's Pew, became the place of royal coronations since 1498, when Dmitrii, the grandson of Ivan III, was crowned there as great prince. In 1547 the cathedral witnessed the coronation of Ivan IV, who assumed the title of tsar. Recollections of this royal ritual defined the program of the Tsar's Pew with its focus on God as the ultimate source of royal prerogatives. $^{40}$ Textual and visual representations of the Monomakh legend in the bas-reliefs of the throne develop this foundation myth.

The program of the Tsar's Pew contains two variants of the legend. The doors of the pew feature a standard text of the Installation with all typical elements, including Vladimir Monomakh's genealogy (fourth generation from St. Vladimir), the anachronistic date of Vladimir Monomakh's campaign (988), the dispatch of troops against Constantinople without Vladimir personally heading them, Constantine's instructions about crowning Vladimir and the conclusion about the continuing tradition of coronation under Vladimir Monomakh's successors. ${ }^{41}$

The bas-reliefs and accompanying inscriptions contain another version of the legend, which, quite surprisingly, only partially follows the text reproduced on the doors. ${ }^{42}$ The overall structure of visual narrative represented in the basrelies is much closer to the murals of the Golden Hall. Both programs of the Golden Hall and the Tsar's Pew culminate in the scene of imperial coronation in Kyiv and omit the standard ending of the legend about the crowning of Vladimir Monomakh's successors.

40 Michael Flier, "The Throne of Monomakh: Ivan the Terrible and the Architecture of Destiny," in Architectures of Russian Identity, 1500 to the Present, ed. James Cracraft, Daniel Rowland (Ithaca: Cornell University Press, 2003), 3132.

41 The doors underwent subsequent alterations and received their present shape in the nineteenth century. Sokolova, Skul'ptura, 27-29, 49, 58 note 10.

${ }^{42}$ Like the text on the doors, the inscriptions of bas-reliefs ignore the name "Cap of Monomachus." The list of imperial emissaries in bas-relief TP-8 is also close to the text carved on the doors whereas corresponding list in the inscriptions of the Golden Hal (as recorded by Klement'ev and Ushakov) is obviously corrupt (GH$4 b)$. 
Another intriguing parallel with the imagery of the Golden Hall can be seen in the Trinity that dominates the scene of Vladimir Monomakh receiving imperial gifts (TP-11). Sokolova links the image of the Trinity with Vladimir's invocation of the Trinity during his conversation with boyars prior to the campaign. The invocation appears in literary adaptations of the legend and in the legend's text carved on the Pew's doors. ${ }^{43}$ But the Pew's bas-relief TP-1 that illustrates the scene of Vladimir deliberating with his boyars and corresponding inscription ignore the Trinity. This suggests that in his representation of Vladimir's reception of Constantine's gifts the master was inspired not by the literary tradition of the legend, but by the program of the Golden Hall, which, as we have seen, featured the Trinity (Paternitas) between the scene of Vladimir receiving imperial regalia and that of his coronation (GH-7a). At the same time, the master of the Pew apparently considered Viskovatyi's criticism of the representation of the Trinity as Paternitas, in particular, the depiction of the invisible God the Father as a human being. ${ }^{44}$ To be on the safe side, the master of the Pew resorted to a more traditional representation of the Trinity as three Old-Testament angels.

Finally, the influence of the program of the Golden Hall is detectable in the Pew's bas-relief TP-2, which represents Vladimir on horseback leading a group of cavalrymen out of city gates. In Muscovite art, such images of a mounted prince usually mark the beginning of a campaign. ${ }^{45}$ The bas-relief is obviously a reflection of the scene of Vladimir personally participating in the campaign against Constantine as represented in the imagery of the Golden Hall (GH-3a). Morozov and Chernetsov believe that the representations of the legend in the murals of the Golden Hall and in the bas-reliefs of the Tsar's Pew stem from a

\footnotetext{
43 Sokolova, Skul'ptura, 26, 57 note 2. Cf. Dmitrieva, Skazanie, 176, 183.

${ }^{44}$ On Viskovatyi criticizing the new images in the Kremlin, including Paternitas, at least three years before the autumn of 1553, see Miller, "The Viskovatyi Affair," 300, 309-311.

45 D. S. Likhachev, Poetika drevnerusskoi literatury in D. S. Likhachev, Izbrannye raboty $v$ trekh tomakh 1 (Leningrad: Khudozhestvennaia literatura, 1987): 308.
} 
common source. ${ }^{46}$ However, the inscriptions of corresponding bar-reliefs do not contain any text supporting the above-mentioned non-standard scenes that have parallels in the images of the Golden Hall. This suggests that the program of the Pew utilized the images of the Hall rather than a common text.

The murals of the Golden Hall provided an influential model for the master of the throne, but he was anything but a mere imitator. The illustrative program of the Tsar's Pew developed the imagery of the Golden Hall by dramatically expanding the account of Vladimir Monomakh's military campaign. Unlike the illustrative cycle in the Golden Hall, which included only one battle scene involving Vladimir's troops (GH-3b), the Pew features as many as five military scenes depicting the march of Vladimir's cavalry in the land of Thrace; Vladimir's troops besieging a Thracian city; a battle between Thracian and Rus' cavalry; a Rus' horseman escorting a cart with booty and prisoners; Rus' cavalry smiting the citizens of a city (TP-3 - TP-6). The last scene, which graphically represents the atrocities of war, is full of expressive details: a fully armed horseman aims a sabre blow at a long-bearded man who tries to protect his head with raised hands; the bodies of killed people lie next to him; a man and a woman seek shelter inside a building while a boy hides in a forest (Fig. 2). ${ }^{47}$

The image of the hiding boy is particularly dramatic: he shrinks his head into his shoulders and turns it to the death dealing cavalryman; the boy's hands in long sleeves are raised to his face, as if he tries to protect himself from imminent danger. Conveying fear and desperation, the boy's image capitalizes on the iconography of similar figures in the fourteenth-century Trinity copy of the Chronicle of Georgios Amartolos. We hardly need to follow here Podobedova who assumed some Russian folklore tradition behind this iconography.48

\footnotetext{
46 Morozov, Chernetsov, "Legenda," 369.

47 On war scenes in the program of the Pew, see Sokolova, Skul'ptura, 26-27, 55. On the representation of violence in Muscovite art, see Bogatyrev, "The Heavenly Host."

${ }^{48}$ Nauchno-issledovatel'skii otdel rukopisei Rossiiskoi gos. biblioteki, f. 173.I, no. 100, ff. 64, 227:

http://old.stsl.ru/manuscripts/medium.php?col=5\&manuscript=100\&pagefile= $\underline{100-0001}$ (last visited 12 February 2016); O. I. Podobedova, Miniatiury russkikh
} 
Grieving figures with hands in long-sleeved garments raised to their faces are typical of the iconography of the Dormition and the Descent into Hell. There are also parallels with the Byzantine iconographic type of the katafigi (refuge) Mother of God that represented the grief-stricken Virgin pressing her omophorion against her cheek. ${ }^{49}$

In early iconography human figures with long sleeves raised to their faces expressed elevated sorrow. The master of the Tsar's Pew reinterpreted this image by associating it with physical and emotional suffering caused by Vladimir's campaign. In the bas-reliefs of the Tsar's Pew, a dramatic figure with raised sleeves appears not only in the above mentioned battle scene, but also in the bas-relief representing Emperor Constantine Monomachus sending his regalia to Kyiv (TP-9, Fig. 3). 50 This sorrowful image dramatizes the representation of the Monomakh legend in the images of the Tsar's Pew. The grieving figure witnessing the dispatch of imperial regalia enhances Vladimir's image as a triumphant military leader, who obtains the regalia by inflicting fear on his enemies. The interpretation of the legend in the bas-reliefs of the throne is very far from peace and harmony that allegedly dominated the works of the Makarian school in the 1550 s. $^{51}$

Why was the master of the Tsar's Pew so preoccupied with violence and military force? K. Iu. Erusalimskii correctly puts the creation of the Pew in the context of Ivan IV's attempts to get his title of tsar recognized by foreign rulers, first of all the Polish king. In 1549 Sigismund II Augustus of Poland rejected Muscovite

istoricheskikh rukopisei. Kistorii russkogo litsevogo letopisaniia (Moscow: Nauka, 1965), 29 (quotes the second pagination of the manuscript).

49 See G. V. Popov, Zhivopis' i miniatiura Moskvy serediny XV - nachala XVI veka (Moscow: Iskusstvo, 1975), nos. 131, 136, 177, 178; E. S. Smirnova, Moskovskaia ikona XIV-XVII vekov (Leningrad: Avrora, 1988), 33; Ia. V. Bruk, L. I. Iovleva, Drevnerusskoe iskusstvo X-nachala XV veka (Gos. Tret'iakovskaia galereia. Katalog sobraniia 1, Moscow: Krasnaia ploshchad', 1995), 57-59, 91-93; Byzantium. Faith and Power, 1261-1557, ed. Helen C. Evans (New York, New Haven, CT:

Metropolitan Museum of Art, Yale University Press, 2004), 198-99, no. 117.

50 Sokolova, Skul'ptura, 40-41.

51 Cf. Flier, "Throne," 32; Nancy Shields Kollmann, Crime and Punishment in Early Modern Russia (Cambridge, UK: Cambridge University Press, 2012), 319-320. 
claims on the title of tsar which were based on the Monomakh legend. Sigismund noted that Vladimir Monomakh was prince of Kyiv, which belonged and, with God's help, would remain belonging to the Polish king. Hence the only monarch who could legitimately claim the "Kyivan tsardom" was Sigismund himself. As Erusalimskii notes, Sigismund's statement suggested that the title of tsar required the possession of a tsardom rather than genealogical continuity or coronation. In December 1550 the Muscovite court confronted Sigismund's argument by juxtaposing possession and conquest. Instructions for Ivan IV's ambassadors elaborated on the Monomakh legend by stressing that Ivan IV inherited the Russian tsardom because his ancestor Vladimir Monomakh received imperial regalia after his campaign against Constantine Monomachus, allegedly also Ivan's ancestor. ${ }^{52}$

This line of reasoning has direct parallels with the program of the Tsar's Pew, including its numerous battle scenes, the dramatic representation of Constantine dispatching his regalia to the triumphant Vladimir, and the citizens of Constantinople mourning the loss of the imperial insignia (as expressed in the grieving figure with raised arms) The location of this new, more violent interpretation of the Monomakh legend in the Dormition cathedral suggests that it was designed to be visible not only to members of the Muscovite elite, but also to Orthodox Lithuanian magnates: when on diplomatic mission in Moscow, they could visit the Dormition and observe there the tsar in his magnificent pew. ${ }^{53}$

In addition to battle scenes, the master of the Tsar's Pew expressed his view of the legend by creatively manipulating the symbolism of royal headgear. In Muscovite iconography the design of a headdress was a tool for marking the title of its bearer. Muscovite tsar and foreign rulers of a similar status, like Byzantine emperors, Mongol khans and Western kings usually had pointed crowns (radiant

\footnotetext{
${ }^{52}$ Kniga posol'skaia Metriki Velikago kniazhestva Litovskago, soderzhashchaia $v$ sebe diplomaticheskiia snosheniia Litvy v gosudarstvovanie korolia SigismundaAvgusta s 1545 po 1572 god 1, ed. M. Obolenskii, I. Danilovich (Moscow: Universitetskaia tipografiia, 1845): 51; Sbornik Imperatorskago Russkago istoricheskago obshchestva 59 (Moscow: Tipografiia F. Eleonskogo i Ko, 1887): 345 (hereafter Sbornik RIO); Erusalimskii, "Istoriia," 689-690. 53 Sbornik RIO 59: 462.
} 
crowns with rays). At the same time, princes, whose hierarchical position was lower than that of tsars, appeared in various hats. This rule applied even to the Muscovite tsar's ancestors who had the title of great prince, including Vladimir Monomakh. 54

In the images of the Tsar's Pew, Vladimir Monomakh's headdress is of a conical shape, in some bas-reliefs with fur brim and a cross on top. What is interesting is that the master also used this pattern for the Cap of Monomachus despite its imperial status. In other words, Vladimir's coronation did not affect the way his headgear looked (TP-1, TP-11, TP-12, Figs. 1, 5). This iconographic paradox can be explained in the context of the literary tradition of the legend. Its literary adaptations (Tale and Installation) end with a controversial statement that since Vladimir Monomakh, who became tsar after his coronation, great princes of the Vladimir principality had been crowned with the imperial crown (tsarskym ventsem) that was sent by Constantine Monomachus when they ascended the throne of the Great Principality of Rus' (velikoe kniazhenie ruskoe). ${ }^{55}$ This means that despite Vladimir Monomakh's title of tsar and the crowning of his successors with the imperial cap, their domain was still a great principality, not a tsardom. The literary tradition of the legend, which took shape before Ivan IV's coronation as tsar, exposed a contradiction between the ruler's imperial claims on the one hand, and his official title of great prince and, correspondingly, the political status of his realm as great principality on the other. The master of the pew sought to resolve this dilemma in the symbolism of imperial headgear. ${ }^{56}$

54 The design of headgear depended on the title of its bearer only in the images of male royalty. Royal women usually appeared in pointed crowns regardless of their title or age. A. V. Artsikhovskii, Drevnerusskie miniatiury kak istoricheskii istochnik (Tomsk, Moscow: Vodolei, 2004), 163-173 (first published in 1944). On the representation of Muscovite royal headgear, including the Cap of Monomachus, in Western and Muscovite art in the sixteenth century, see Sergei Bogatyrev, "Bronze Tsars: Ivan the Terrible and Fedor Ivanovich in the Decor of Early Modern Guns," Slavonic and East European Review 88, 1-2 (2010): 53-60, 68.

55 Dmitrieva, Skazanie, 178, 184; PSRL 7: 23.

${ }^{56}$ Makarii's Great Menology offers a different solution by substituting "great principality" with "Russian tsardom" (Rosiiskom tsarstvii) in the text of the legend. The master of the Pew was not prepared for such radical alterations, indicating that he obviously did not belong to Makarii's circle. VMCh, col. 1318. 
Despite his coronation with the imperial Cap of Monomachus, Vladimir's headgear always looks like a princely hat because it refers to the great principality of Rus' mentioned in the legend.

This iconographic decision required flexibility in the representation of the Byzantine emperor's headgear. In bas-reliefs showing Constantine as Vladimir's enemy prior to his campaign against Byzantium, the emperor wears not an imperial crown, but a cap of a conical shape similar to that of Vladimir (TP-8, TP9). ${ }^{57}$ This iconographic devise helped visualize the idea of transferring the cap from Constantinople to Kyiv. But after making peace with the prince of Kyiv, Constantine appeared in a typical imperial crown with rays, a sign of restored hierarchy of rulership (TP-10, Fig. 4). Such experiments with the symbols of royal status reveal the master's reflections about how his violent interpretation of the Monomakh legend would fit in the grand narrative of royal power. The program of the Tsar's Pew addresses the tension between the eternal hierarchy of rulership and the conquest of imperial regalia, between established order and violent change.

\section{The Illustrated Chronicle Compilation}

Reflection on visual images and experimentation with symbols are even more conspicuous in the program of the Illustrated Chronicle Compilation. The sheer size of the chronicle, which contains about 16,000 miniatures, some of them unfinished and revised, helps us to trace the different attitudes of artists and editors to the visual representation of royal power. The chronicle miniaturists had a complex relationship with earlier illustrations to the Monomakh legend created by the masters of the Golden Hall and the Tsar's Pew. On the one hand, the chronicle cycle of miniatures has many compositional parallels with those

${ }^{57}$ Morozov and Chernetsov believe that the master sought to depict the real Cap of Monomachus that is kept now in the Kremlin Armory. This view assumes realism that was not typical of Muscovite art. Morozov, Chernetsov, "Legenda," 370 . 
programs. ${ }^{58}$ The illuminators also utilized and even expanded the symbolism of some illustrative devices borrowed from the bas-reliefs of the Tsar's Pew. In particular, they reproduced sorrowful figures covering their faces with raised hands in many miniatures representing grief at deathbed and funerals, as well as suffering caused by war, natural calamities and divine wrath. ${ }^{59}$

At the same time, the miniaturists were very selective in their attitude to the imagery of the Tsar's Pew. Unlike the master of the Tsar's Pew, they refrained from reproducing grieving figure in their illustrations to the Monomakh legend. The reason for that exclusion was a different perspective on the story about imperial regalia in the chronicle. Its interpretation of the legend prioritized peace and consultation over military violence. The Illustrated Chronicle Compilation places the legend within a larger "historical" account of Vladimir Monomakh's reign which is based on earlier chronicles. In particular, the legend is preceded by an introduction to Vladimir Monomakh's reign which tells us about his genealogy, arrival in Kyiv, and ascension to the Kyivan throne. It is that introduction that sets the scene for the image of Vladimir as a peacemaker by reporting that he brought joy to the citizens and appeased mutinies that engulfed Kyiv prior to his arrival (liudie vozradovashasia, a miatezh oulezhe, Fig. 6).60

58 Those include scenes representing consultation between Vladimir Monomakh and his boyars (GH-1, TP-1, ICC-1; Figs. 1, 7), Constantine Monomachus' military campaigns (GH-4a, TP-7, ICC-6) and the crowning of Vladimir Monomakh by the emperor's representative Metropolitan Neophyte (GH-7b, TP-12, ICC-11, Figs. 5, 8).

59 Death and illness: $L L S-B I$ 1: 321-323, 332, 2: 321; LLS-RLI 19 (Moscow: Akteon, 2010): 301. Divine wrath: $L L S-B I$ 1: 378, 389; LLS-BI 2: 109; 155. War devastation: LLS-RLI 10 (Moscow: Akteon, 2010): 199; 19: 203, 419; 20 (Moscow: Akteon, 2010): 38. Fires, starvation, freezing, pest and wild animal outbreak: LLS-RLI 7 (Moscow: Akteon, 2009), 142; 8 (Moscow: Akteon, 2009): 279, 318, 444; 12 (Moscow: Akteon, 2010): 397. On the representation of natural calamities in the Illustrated Chronicle Compilation in general, see Podobedova, Miniatiury, 298.

${ }^{60}$ Coming from the Voskresenskaia and Nikonian chronicles, this introduction was not originally part of the literary tradition of the Monomakh legend that is reflected in the Tale and Installation. PSRL 7: 23 (Voskresenskaia); PSRL 9 (Moscow: Iazyki russkoi kul'tury, 2000): 143-144 right column (Nikonian); LLSRLI 1: 2 (Illustrated Chronicle Compilation). 
The introduction is followed by the chronicle version of the Monomakh legend that develops the peaceful image of Vladimir Monomakh. Chronicle illustrations to the legend present him as an enthroned ruler engaged in calm consultation with his advisors. ${ }^{61}$ The theme of restored harmony culminates at the end of the chronicle story about the origin of imperial regalia. Unlike the programs of the Golden Hall and the Tsar's Pew, the chronicle reproduces the legend's conclusion about Vladimir living in peace with Constantine after receiving imperial gifts. Images of both rulers tranquilly conversing with their advisors visualize the idea of prevailing peace (ICC-12, ICC-13, Fig. 9).

Like the master of the Tsar's Pew, the chronicle miniaturists coordinated the design of Vladimir Monomakh's headgear and that of the Cap of Monomachus with his official title of great prince, which did not change after his coronation; hence the same pattern of Vladimir's cap before and after the coronation in the miniatures (Figs. 7-9). ${ }^{62}$ However, the design of the Cap of Monomachus in the miniatures differs from that in the bar-reliefs of the Tsar's Pew. In their illustrations to the legend the miniaturists represented the cap as a yellow halfcircle with ornament, apparently implying a golden headgear of a semispherical shape akin to a miter (Figs. 8, 9). Furthermore, in other parts of the chronicle, including the above-mentioned introduction to Vladimir Monomakh's reign, he

61 The Tsar's Pew features only one scene showing Vladimir on the throne conversing with his boyars (TP-1) as opposed to two images of the enthroned Vladimir deliberating with his boyars in the Golden Hall (GH-1, GH-6a). In the chronicle version of the legend we can see three compositions representing communication between the enthroned Vladimir and his boyars (ICC-1, ICC-8, ICC-12).

62 Similarly, the chronicle miniatures representing Dmitrii the Grandson's coronation as grand prince in 1498 feature the Cap of Monomachus depicted as a princely hat because the coronation did not bring Dmitrii an imperial title. On the contrary, miniatures illustrating the chronicle account of Ivan IV's coronation in 1547 usually represent the Cap of Monomachus as a pointed imperial crown which marks Ivan's new imperial title, that of tsar. LLS-RLI 17 (Moscow: Akteon, 2010): 363, 365-367, 369, 372-383 (Dmitrii the Grandson); LLS-RLI 20 (Moscow: Akteon, 2010): 313-315 (Ivan IV). On the representation of Ivan IV in the chronicle, see Frank Kämpfer, Das russische Herrscherbild von den Anfängen bis zu Peter dem Grossen: Studien zur Entwicklung politischer Ikonographie im byzantinischen Kulturkreis (Recklinghausen: A. Bongers, 1978), 180-198; V. V. Morozov, "Ivan Groznyi na miniatiurakh Tsarstvennoi knigi," Drevnerusskoe iskusstvo. Rukopisnaia kniga 3 (Moscow: Nauka, 1983): 232-240. 
appears in a different hat, depicted now as a fur-brimmed half circle of red color resembling a soft hat made of some dyed material (Fig. 6).

Different appearances of princely headgear resulted from the complexity of the chronicle project, which involved numerous miniaturists. These artists were engaged in creating the symbolical language of miniatures. Lasting for about fifteen years, this long process involved the assignments, rejections and adjustments of particular symbols. The initial stage of this creative work can be seen in the earliest part of the Illustrated Chronicle Compilation that includes the Biblical account of ancient history. The miniaturists apparently had no conceptual framework for depicting imperial headgear when they started working on the chronicle. This is why the headdress of tsars opposing Joshua in the Biblical part of the chronicle is a mixture of imperial pointed crowns and semispherical miters. ${ }^{63}$ The miter design also appears in the images representing the headgear of Assyrian and Syrian rulers. At some point the symbolism of a miter was extended to the highest priesthood. During the editing of the Illustrated Chronicle Compilation's section containing Exodus the image of Aaron also received headgear in the form of a miter. ${ }^{64}$

Having moved onto East Slavic history, the illuminators allocated miters to local princes whereas the heads of Orthodox clerics usually remained bare. Further adjustments to the symbolism of ceremonial headgear resulted in miters

63 Litsevoi letopisnyi svod XVI veka. Bibleiskaia istoriia 2 (Moscow: Akteon, 2011): 370, 371, 377, 381, 383, 384 (hereafter $L L S-B I$ ).

64 LLS-BI 1 (Moscow: Akteon, 2011): 483. This part of the Illustrated Chronicle Compilation contains reworked folios similar to those in the last part of the chronicle devoted to Ivan IV's reign. Watermark evidence suggests that unlike the editing of the section about Ivan IV, which took place some time after its original version was written and illuminated, the chronicle version of Exodus underwent editing practically immediately after its creation. This means that the editing of the Illustrated Chronicle Compilation was a multi-phase process rather than a one-off event. On the editing of the chronicle account of Ivan IV's reign, see Litsevoi letopisnyi svod XVI v. Metodika opisaniia i izucheniia razroznennogo letopisnogo kompleksa, ed. E. A. Belokon' and others (Moscow: RGGU, 2003), 47; V. V. Morozov, Litsevoi svod v kontekste otechestvennogo letopisaniia XVI veka (Moscow: Indrik, 2005), 30-32, 36; LLS-RLI 24 (Moscow: Akteon, 2010): 379381 . 
becoming the headgear of the highest clergy, first of all metropolitans, while princes received another type of headdress, fur-brimmed soft hats. However, the change in design was reversible, and princes could still appear in miters. ${ }^{65}$

By the time the miniaturists started working on their illustrations to the Monomakh legend, they had developed two different styles for depicting great princely headgear, a soft had and a miter. The choice of style was a matter of individual or group preferences among the illuminators. Generally speaking, the chronicle illustrators of the legend had to follow some basic rules, like correlating the design of headgear with the titles of corresponding rulers. ${ }^{66} \mathrm{At}$ the same time, they were free from centralized micro-management. The editor(s), who sporadically intervened in the working process, tolerated variations in the design of Vladimir Monomakh's headgear and did not question the overall representation of the Monomakh legend in the Illustrated Chronicle Compilation. ${ }^{67}$

The creators of the chronicle version of the legend were primarily concerned about representing the Cap of Monomachus as a symbol of dynastic continuity, a topic that was practically absent from the programs of the Golden Hall and the Tsar's Pew. This is why the chronicle reproduces the legend's conclusion about the coronation of Vladimir Monomakh's successors with the Cap of Monomachus. A miniature illustrating this passage shows a cleric crowning a prince with the cap, which is depicted as a miter. To represent the ritual of coronation as a continuing uninterrupted tradition, the miniaturist duplicated the image of the

65 This follows from the chronicle account of Vasilii III's campaigns against Smolensk in 1513-1514. The design of Vasilii III's headgear in corresponding miniatures changes back and forth between a miter and a soft hat without any logic. LLS-RLI 18 (Moscow: Akteon, 2010): 204, 217, 231, 235, 238, 239, 250, 262. Similar variations can be seen in the chronicle account of Vladimir Monomakh's reign (Figs. 6-9).

${ }^{66}$ Chronicle miniaturists followed this rule more consistently than the master of the Tsar's Pew. In the chronicle illustrations to the legend Emperor Constantine always appears in an imperial crown and never wears the hat intended as a gift for Vladimir.

${ }^{67}$ Miniatures in other parts of the chronicle, especially those illustrating the reign of Ivan IV, underwent intrusive editing. 
cap by depicting it first in the cleric's hand and then on the prince's head (ICC-14, Fig. 9).

The creation of an iconographic cycle required engagement with earlier illustrations and literary texts. During this process Muscovite artists shifted accents and generated new meanings by using major themes in various combinations. In a way, their creative work was similar to the compilation of collected readings (chetii sborniki) in East Slavic literature. William R. Weder compares the cultural function of such collections to a kaleidoscope, in which a limited number of elements (pieces of colored glass) forms new countless patterns by simple rotation. ${ }^{68}$ As the juxtaposition of previously distinct texts in a collection produced new epistemic values, the shuffling of established forms in illustrative cycles generated new perspectives on rulership.

By focusing on different aspects of the foundation myth Muscovite artists created a polyphonic representation of the Monomakh legend in court culture. The murals of the Golden Hall conflated the images of two Vladimir in a timeless image of Orthodox tsardom: the acquisition of imperial regalia paralleled the discovery of Orthodox faith, Moscow mirrored Jerusalem and the East Slavic royalty emulated the Kings of Ancient Israel. This conceptual vision perfectly fitted the location of the murals in the royal throne room, which conveyed the idea of eternal royal power. In his turn, the master of the Tsar's Pew associated the Monomakh legend with the prince's military exploits. His interpretation of tsardom was more circumstantial and experimental as it echoed the ongoing controversy about Muscovite imperial claims. Unlike the early illustrative cycles of the Golden Hall and the Tsar's Pew, the miniaturists of the Illustrated Chronicle Compilation integrated the legend in the chronicle narrative of dynastic succession. The illuminators' aim was to represent harmonious relations

68 William R. Veder, “Old Russia's 'Intellectual Silence' Reconsidered,” in Medieval Russian Culture 2: 26. 
between the prince and his subjects, peace between monarchs and uninterrupted succession of power, as expressed in the repeating ritual of coronation.

The symbolism of royal power varied even within one project. Changes in the designs of royal headgear within the iconographic programs of the Tsar's Pew and the Illustrated Chronicle Compilation testify to the self-reflexivity of Muscovite artists and editors. They sought to achieve both consistency to conform to the standards of Muscovite visual art and flexibility to express their peculiar interpretations of the Monomakh legend. In this respect the Illustrated Chronicle Compilation is very close to the official chronicle of the Moghul Emperor Akbar, the Akbarnama, which was compiled almost simultaneously with the Muscovite chronicle, from 1589 to 1598. Like their Moghul counterparts, Ivan IV's chroniclers inventively used received narrative forms. The compilers of both chronicles desperately sought to comprehend the long and controversial reigns of corresponding rulers, Ivan IV and Akbar, through relentless editing, rewriting and rearranging images even in the final versions of their works. ${ }^{69}$

Where the Moghuls differed from the Muscovites was that Akbar's court celebrated the names of its artists. The anonymity of Muscovite illustrative cycles studied in this paper hampers the identification of their patrons. Nevertheless, different interpretations of the Monomakh legend in practically simultaneous works of art (Golden Hall and the Tsar's Pew) suggest several centers of patronage rather than one omnipotent figure controlling all artistic activities, be it Metropolitan Makarii or Ivan IV. Apparently, there were other members of the elite who possessed creative talents, administrative resources and money to sponsor cultural programs.

${ }^{69}$ Moin, The Millennial Sovereign, 169-70, 202. Other common typological features of the Illustrated Chronicle Compilation and Akbar's chronicle projects include grand scale and engagement with Western art. On Akbar's patronage and the work of his studio, see J. P. Losty and Malini Roy, Mughal India: Art, Culture and Empire. Manuscripts and Paintings in the British Library (London: The British Library, 2012), 27-31. 
The royal imagery of the Golden Hall reveals numerous parallels with the murals of the Annunciation cathedral, which is adjacent to the palace and served as the main ceremonial entrance to it. Like the program of the Golden Hall, the arrangement of royal images in the cathedral defies genealogy and brings out semiotic connections with mythological past. Both programs also share, among other images, representations of the Trinity as Paternitas. ${ }^{70}$ Common features suggest that the murals of the Annunciation and the Golden Hall were commissioned by the same patron, most likely by somebody from the clergy of the Annunciation cathedral. The names of several clerics associated with the Annunciation appeared during the investigation of Secretary Ivan Viskovatyi's complaints about the redecoration of the cathedral and the palace after the fire of 1547: priests Sil'vestr, Simeon, Vasilii and Archpriest Andrei (future Metropolitan Afanasii). ${ }^{71}$

Two of them, Sil'vestr and Andrei were prominent figures in Muscovite culture, but Andrei became head of the Annunciation clergy only in 1550 when the restoration project was already under way. At the same time, Sil'vestr had been associated with the Annunciation from 1545-46. Modern scholarship rejects the idea that he was in charge of the government in the $1550 \mathrm{~s}$, but does this view mean that he was unable to launch a cultural initiative? Students acknowledge Sil'vestr's contribution to the renovation of the Kremlin after the 1547 fire, but

70 On royal imagery in the Annunciation, see Jaakko Lehtovirta, Ivan IV as Emperor: The Imperial Theme in the Establishment of Muscovite Tsardom (Turku: Painosalama, 1999), 173-174; I. Ia. Kachalova, "Tsarskii khram," in M. V. Vilkova and others, eds., Tsarskii khram: Sviatyni Blagoveshchenskogo sobora v Kremle (Moscow: Maksim Svetlanov, 2003), 8-23; T. E. Samoilova, "Tema tsarskoi i kniazheskoi sviatosti v rospisiakh Blagoveshchenskogo sobora," in Vilkova, Tsarskii khram, 24-38. On Paternitas in the Annunciation, see Retkovskaia, "0 poiavlenii," 256; Podobedova, Moskovskaia shkola, 40-58; I. Ia. Kachalova and others, Blagoveshchenskii sobor Moskovskogo Kremlia: K 500-letiiu unikal'nogo pamiatnika russkoi kul'tury (Mocsow, Iskusstvo, 1990), 61-62.

${ }^{71}$ O. Bodianskii, “Rozysk ili spisok o bogokhul'nykh strokakh i o sumnenii sviatykh chestnykh ikon diaka Ivana Mikhailova syna Viskovatogo v leto 7062," Chteniia v Imperatorskom Obshchestve istorii i drevnostei rossiiskikh (hereafter ChOIDR), 1858, book 2 (April-June): section “III. Materialy slavianskie," 15, 31, 40 . 
reduce his role to technical supervision assuming that the main driving force behind the project was Metropolitan Makarii or even Ivan IV himself.72

The proceedings of the church council, which examined Viskovatyi's criticism in January 1554, cast doubt on assertions about the patronage of the tsar and metropolitan. After receiving Viskovatyi's complaints, Makarii forwarded them to the tsar, who, in his turn, returned them to the metropolitan with instructions to convoke a church synod..$^{73}$ These are not actions of patrons caring about their pet project. Rather, one can see here two highest authorities trying to shift responsibility for dealing with a nuisance. Furthermore, Sil'vestr urged Makarii to investigate painted images to ensure that the priest did not add anything new to established iconpainting models. ${ }^{74}$ If Makarii had designed or approved the images, he should have known them without Sil'vestr's encouragement.

During the investigation of the Viskovatyi case, nether Viskovatyi nor Sil'vestr mentioned Makarii's or Ivan IV's engagement with the imagery of the Annunciation cathedral or the royal palace. General and repetitious, Makarii's statements at the council could have been prepared by his aids. Sil'vestr, on the contrary, provided a detailed account of the restoration project and openly acknowledged that he instructed his masters to paint certain icons. ${ }^{75}$ This information fits Sil'vestr's cultural profile: he was well educated, owned books in Greek, taught orphaned and poor people iconpainting and enjoyed authority among cultured Muscovites. ${ }^{76}$ It is the clergy of the Annunciation, and Sil'vestr in

72 Podobedova, Moskovskaia shkola, 15, 17-18; Kachalova, “Tsarskii khram,” 14. Podobedova did acknowledge that Makarii's role in the organization of the project was passive.

73 Bodianskii, “Rozysk," 2.

74 O. Bodianskii, "Moskovskie sobory na eretikov XVI veka v tsarstvovanie Ivana Vasil'evicha Groznago," ChOIDR, 1847, no. 3: section “II. Materialy otechestvennye," 21

75 Bodianskii, "Moskovskie sobory," 19.

76 The Domostroi. Rules for Russian Households in the Time of Ivan the Terrible, ed. Carolyn Johnston Pouncy (Ithaca and London: Cornell University Press, 1994), 184; Carolyn Johnston Pouncy, “'The Blessed Sil'vestr' and the Politics of Invention in Muscovy, 1545-1700," Harvard Ukrainian Studies 19, Kamen' Kraeug"l'n": Rhetoric Of The Medieval Slavic World (1995): 550; A. I. Filiushkin, 
particular, who should be credited for the sophisticated representation of the Monomakh legend in the Golden Hall.

The location of the Tsar's Pew in the Dormition cathedral, which was of course the metropolitan's church, suggests that the visual program of the throne received Metropolitan Makarii's approval. Still, judging by the relevance of the imagery of the Tsar's Pew to contemporary diplomatic controversy over Ivan IV's title, the main driving forces behind the program were most likely some court circles. Scholars agree now that members of Ivan IV's court elite sponsored projects in Orthodox art, architecture and book culture. ${ }^{77}$ During the preparation of his critical comments, Viskovatyi contacted several prominent courtiers, including M. Ia. Morozov, a scion of an established boyar family, who lent Viskovatyi a copy of John of Damascus. In his capacity of the tsar's ambassador to Poland in 1549, Morozov evoked the Monomakh legend as a justification for Ivan IV's title of tsar during negotiations with Sigismund. It was precisely Morozov to whom Sigismund addressed his above-mentioned rebuff to Muscovite attempts to claim the memory of Vladimir Monomakh of Kyiv. ${ }^{78}$ Cultured courtiers like Morozov, who were engaged in the diplomatic debate with Poland-Lithuania over Kyivan inheritance, could have been responsible for the appearance of the militarized interpretation of the Monomakh legend in the imagery of the Tsar's Pew.

Finally, the version of the legend presented in the Illustrated Chronicle Compilation brings us to an interest group that embraced a dynastic vision of Muscovite past and prioritized the practice of consultation between the ruler and

Istoriia odnoi mistifikatsii: Ivan Groznyi i "Izbrannaia Rada” (Moscow: VGU, 1998), 316.

77 Daniel Rowland, "Architecture and Dynasty: Boris Godunov's Uses of Architecture, 1584-1606," in Architectures, 34-47; Edward L. Keenan, "The Stepennaia Kniga and the Godunovian Renaissance," in The Book of Royal Degrees and the Genesis of Russian National Consciousness, ed. Gail Lenhoff, Ann Kleimola (Bloomington, IN: Slavica Publishers, 2011), 69-79.

78 Bodianskii, "Rozysk," 8, 15, 16; Sbornik RIO 59: 309; Obolenskii, Danilovich, Kniga, 51. On M. Ia. Morozov, see Nancy Shields Kollmann, Kinship and Politics: The Making of the Muscovite Political System, 1345-1547 (Stanford, CA: Stanford University Press, 1987), 220. 
the elite. Such practice was a traditional feature of the Muscovite political system. ${ }^{79}$ However, by the 1570 s, when the work on the illustrated chronicle was in full swing, the idea of advice had been compromised by Ivan IV's divisive policy of alienating the elite through accusations of treason. Those who advocated the normalization of Muscovite politics must have been eager to bring the idea of consultation to the chronicle narrative. The patrons of the chronicle variant of the legend had much in common with Metropolitan Afanasii (former Archpriest Andrei of the Annunciation). His contribution to Muscovite culture has been overshadowed by the inflated concept of the Makarian school, but it is clear now that Afanasii was anything but an epigone of Makarii. ${ }^{80}$ As we have seen, Afanasii actively promoted a genealogical interpretation of Muscovite history in the 1560s. He also mediated a conflict between Ivan IV and his subjects urging the tsar to return to the capital after the establishment of the Oprichnina. Afanasii most likely died before the compilation of the Illustrated Chronicle Compilation, but his followers apparently contributed to the project. ${ }^{81}$ We can thus assume that people who shared Afanasii's vision of Muscovite history and politics sponsored the representation of the Monomakh legend in the Illustrated Chronicle Compilation.

All these groups operated through their own patronage networks making Muscovite cultural practices much more diverse than traditional scholarship assumes. It would be misleading to see these groups as political parties or factions. A polycentric view of court art does not mean returning to the

\footnotetext{
${ }^{79}$ Daniel Rowland, "The Problem of Advice in Muscovite Tales about the Time of Troubles," Russian History 6 (1979): 259-83; Sergei Bogatyrev, The Sovereign and His Counsellors: Ritualised Consultations in Muscovite Political Culture, 1350s1570s (Helsinki: Finnish Academy of Science and Letters 2000).

80 Sergei Bogatyrev, "The Resignation of Metropolitan Afanasii in 1566," Canadian-American Slavic Studies 49 (2015), 2-3: 174 - 192.

81 A. S. Usachev, "Mitropolit Afanasii i pamiatniki russkogo letopisaniia seredinytret'ei chetverti xvi v.," in Letopisi i khroniki. Novye issledovaniia. 2011-2012 (Moscow, St. Petersburg: Al' ians-Arkheo, 2012), pp. 253-274; Bogatyrev, "Resignation," 187-191. Afanasii's resignation did not affect people from his entourage. Thus, his secretary Nikita Parfeniev continued to work for Afanasii's successor Metropolitan Philip Kolychev. Akty, sobrannye v bibliotekakh $i$ arkhivakh Rossiiskoi imperii Arkheograficheskoiu ekspeditsieiu 1 (St. Petersburg: Tipografiia II Otdeleleniia SEIV kantseliarii, 1836): no. 266, p. 302.
} 
exhausted view of Muscovite culture as a battleground for different political forces, like the Josephites versus the Non-Possessors or the "conservative boyars" versus the "progressive gentry." Only one of three interpretations studied here, that in the Illustrated Chronicle Compilation contains indirect criticism of contemporary politics. But generally polyphony did not imply radical denial of authority and its official representation. Even in politicized Tudor society various interest groups did not reject, but competed for authorized representations claiming the monarch as their patron. ${ }^{82}$ Similarly, Muscovite sponsors of court art shared an Orthodox view of Muscovite rulership, but promoted in their projects different aspects of the Muscovite origin myth. Interpretations varied depending on the preferences of individual patrons or interest groups sponsoring particular projects. Meanings could also shift in response to the perception of Muscovite mythology by the audience, like foreign royalty, with whom Ivan IV strived to be on par, or domestic critics, like Viskovatyi, some of whose critical comments were accepted by the ecclesiastical authorities. Finally, artists' self-reflection also contributed to different perspectives on the Monomakh legend. Muscovite patrons and artists developed a dialogue as they formulated, revised and adjusted the symbolical language of their projects. This dialogue was much more subtle than open Renaissance debates or the sophisticated polemics of Islamicate scholars. Still, Muscovite culture allowed negotiations about meanings.

School of Slavonic and East European Studies

University College London

Gower Street

London

WC1E 6BT

United Kingdom

s.bogatyrev@ucl.ac.uk

82 Susan Frye, Elizabeth I: The Competition for Representation (New York, Oxford: Oxford University Press, 1993); Sharpe, Selling, 26, 320. 
